\title{
Malignant Epiglottis Neoplasm
}

National Cancer Institute

\section{Source}

National Cancer Institute. Malignant Epiglottis Neoplasm. NCI Thesaurus. Code C4836.

A malignant neoplasm that affects the epig lottis. The vast majority of cases are squamous cell carcinomas. 